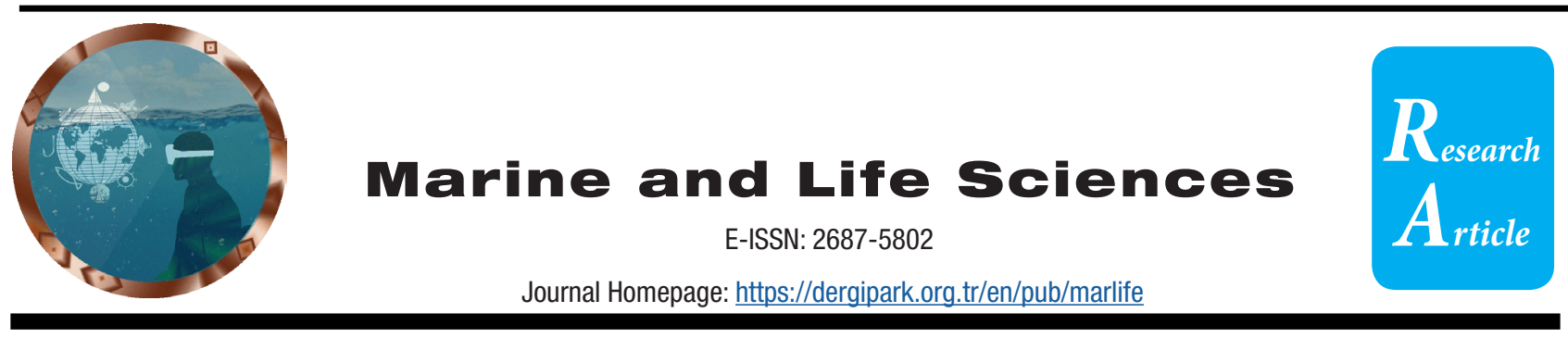

\title{
The effect of different salinity levels on larval growth and survival of Farfantepenaeus aztecus (Ives, 1891) (Decapoda: Penaeidae)
}

\author{
Ahu Deniz Uludağ ${ }^{1}$, Mevlüt Aktaș ${ }^{2 *}$
}

*Corresponding author: mevlut.aktas@iste.edu.tr

Received: 19.11 .2021

Accepted: 10.12 .2021

\begin{tabular}{l} 
Affiliations \\
\hline 'Program of Aquaculture, Institute of \\
Graduate Studies, Iskenderun Technical \\
University, Iskenderun, Hatay, TURKEY \\
2Department of Aquaculture, Faculty \\
of Marine Science and Technologies, \\
İsenderun Technical University, \\
Iskenderun, Hatay, TURKEY
\end{tabular}

Keywords

Farfantepenaeus aztecus

Salinity

Larvae

Micro-algae

Culture

\begin{abstract}
This study was designed to determine the effects of five different salinity levels (25, 30, 35, 40 and $45 \mathrm{ppt}$ ) on the survival rate of Farfantepenaeus aztecus larvae from Nauplius5 to post-larvae1 (N5-PL1). For this purpose, 50 larvae that reached the N5 stage were stocked in 2-L round bottom glass flasks in five replications and were grown up to the PL1 stage at $27.6 \pm 0.4^{\circ} \mathrm{C}$. At the end of the study, as the highest survival $(44.00 \pm 23.15)$ in protozoal stages were obtained at 35 ppt salinity levels, the lowest survival $14.00 \pm 4.89$ ) were found at $25 \mathrm{ppt}$ salinity levels $(P<0.05)$. The highest survival rates from the $M 1$ stage to the

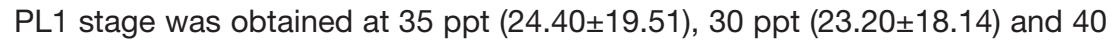
ppt, respectively. The survival rates at 25 and 45 ppt salinity levels were found statistically different from those of 30,35 , and 40 ppt $(P<0.05)$. The results of this study show for the first time that the optimum salinity level is the range of 30-40 ppt for larval culture obtained from the North-eastern Mediterranean population of brown shrimp that is the West Atlantic natural origin.
\end{abstract}

\section{Introduction}

The effects of environmental conditions on the survival and growth of penaeid shrimps are widely known during the culture cycle by the aquaculturist. Water temperature, salinity, turbidity and oxygen content are the most critical parameters in the hatchery phase. While the dissolved oxygen and turbidity usually vary depending on the presence of the biological community in the tanks, temperature and salinity provide an opportunity to perform simple experiments to isolate the influence of the environmental parameter. Although the effect of salinity on survival has a more negligible impact when compared to temperature (Parado-Estepa, 1998), its effects on growth is unclear. The osmoregulation and ion balance, which support the survival rate and thus growth, increase the energy need. In the natural environment, most adult penaeid shrimp spawn in oceanic waters; egg incubation and larval stages are completed in this environment. On the other hand, most penaeid shrimps spend most of their lives in estuarine waters and may be euryhaline. It is accepted that penaeid shrimps are not equipped with the capabilities of withstanding major environmental changes during their larval development. In summary, it is necessary to understand the effect of salinity on survival and growth during larval stages.

Although numerous studies have been carried out to determine the optimum salinity in larval stages of different species of penaeid shrimp, the results are quite conflict (Venkataramaiah et al.,1972; Gopalakrishnan, 1976; Preston, 1985; Chu and So, 1987; Charmantier et al., 1988; Staples and Heales, 1991; Kumlu and Jones, 
1995; Kumlu, 1998; Kumlu et al., 1999; Kumlu et al., 2000; Xinhong, et al., 2005). As a result, it has been reported that extreme salinities increase the mortality rate for penaeid shrimp if adaptation is not applied (Lester and Pante, 1992). In addition, it is known that response to the salinity is speciesspecific and both salinity and temperature may interact to influence survival and growth (Staples and Heales, 1991; O’Brien, 1994).

The brown shrimp Farfantepenaeus aztecus (Ives, 1891 is commonly distributed throughout the northwestern Atlantic Ocean (Perez Farfante, 1969). The shrimp which is a species of Atlantic origin, was first reported from the Mediterranean in 2010 (Deval et al., 2010). Then, there are reports of its existence from different regions of the Mediterranean (Gökoğlu and Özvarol, 2013; Kapiris et al., 2014; Minos et al., 2015). The anglers commercially caught the species throughout the Eastern Mediterranean. However, it is reported that the species is important for aquaculture and recreational fishing (Castaneda et al., 2012). Most studies in the literature concentrated on salinity tolerance in postlarval and juvenile stages of F. aztecus (Zein Eldin and Griffith, 1965; Venkataramiah et al., 1974; Saoud and Davis, 2003). On the other hand, studies on the period from spawning to the postlarval period are very few, and there is no information about the salinity tolerance in culture conditions. In order to produce high quality post larvae and to define adequate conditions for optimal post-larval production of $F$. aztecus in controlled conditions, it is necessary to know the salinity tolerance in the larval stages and to reveal the optimal salinity.

The aim of this study is to contribute to the development of larval culture protocols for brown shrimp breeding. In this context, this study was designed for the first time to determine the optimum salinity level at which the highest survival rate can be achieved for the brown shrimp population in the North-eastern Mediterranean Sea.

\section{Material and Methods}

This study was conducted at the Marine Fish and Crustacean Research Station of Faculty of Marine Sciences and Technology, Iskenderun Technical University in İskenderun, Hatay, Turkey. Brown shrimp, Farfantepenaeus aztecus nauplius was obtained from a female caught in the $4^{\text {th }}$ gonad stage from the Iskenderun Bay in the Northeastern Mediterranean Sea. The female brown shrimp were spawned in an 80-liter (polyethene material, radius: 50 , height: $60 \mathrm{~cm}$ cylindric) black tank. The water used in the tank was filtered $(1 \mu \mathrm{m})$ and UV irradiated. The spawning tank supplied oxygen with moderate aeration. Hatching of eggs took place here, and nauplii were left in this tank until the Nauplius 5 (N5) stage, and then all the larvae were harvested with plankton net $(200 \mu \mathrm{m})$ utilizing their phototaxis. Larvae that reached the N5 stage were transferred to the test environments after the 2 hours of acclimatisation. In the process the water salinity were changed at $2 \mathrm{~g} \mathrm{~L}^{-1}$ every 15 minutes (Preston, 1985; Kumlu, 1997). Freshwater (reversed osmose), seawater mixtures and artificial sea (Caledonia Reef Salt, ReeFlowers, Istanbul) were used to reach 40 and 45 ppt levels. A salinometer YSI 30 (Yellow Springs Instrument Company, Inc. Yellow Springs, Ohio) measured water temperature and salinity.

To determine the effects of five different salinity levels $(25,30,35,40,45 \mathrm{ppt})$ on survival and development from the N5 stage to the PL1 stage, the browns shrimp larvae were stocked in 2-L round-bottom glass flasks in five replicates at a density of 25 nauplii $\mathrm{L}^{-1}$. Then, to keep the water temperature constant at $27.6 \pm 0.4^{\circ} \mathrm{C}$, the glass flasks were placed in a thermostatically controlled water bath.

The micro-algae mixture consisting of Tetraselmis chuii (30 cells $\mu \mathrm{L}-1)$, Phaeodactylum tricornitum ( 25 cells $\mu \mathrm{L}-1)$, Chaetoceros calcitrans (50 cells $\mu \mathrm{L}-$ 1) and Isochrysis galbana ( 25 cells $\mu \mathrm{L}-1)$ was given to the larvae throughout the experiment. Newly hatched Artemia salina was given five nauplii $\mathrm{mL}^{-1}$ from the Mysis1 (M1) to the PL stage. All of the glass flasks were emptied and larvae were counted with the help of a lightbox to determine the survival rates at the end of the mysis and protozoea stages. The following formula was used for determining the survival rate for each stage

Survival rate (Protozoea): Total number of protozoea / Total number of nauplii x 100

Survival rate (Mysis) Total number of mysis / Total number of protozoea $\times 100$

Survival rate $(\mathrm{PL})$ : Total number of $\mathrm{PL} /$ Total number of mysis $\mathrm{x} 100$

\section{Statistics}

The data were analysed using the Statistical Package for the Social Sciences software (SPSS, 2012, Version 17.0, SPSS, Chicago, IL, USA). The results were subjected to Levene's test to determine homogeneity of variance, and no transformation was required. One-way ANOVA used a post hoc Duncan's multiple range test to determine the mean survival rate differences 
among the treatments. Differences were considered significant at the 95\% confidence level $(\mathrm{P}<0.05)$. All means were presented with \pm standard deviation (SD).

\section{Results}

Nauplii reached the post-larval stage at all tested salinity levels. However, different salinity levels had significant effects on survival from the protozoeal stage to the mysis stage and from the $M$ stage to the post-larval $(P L)$ period $(P<0.05)$ (Table 1$)$. The best survival rate between protozoea and mysis periods was found at 35, 40 and 30 ppt salinity levels, respectively. The larvae reared at 25 , and 45 ppt salinity levels had the lowest larval survivals from PZ1 to M1 (Figure1). Considering the survival rates from the $M 1$ stage to the PL1 period, the best survival rate was found at 35 ppt (24.40\%), 30 ppt (23.20\%), and 40 ppt (16.80\%) salinity levels. The survival rate of the larvae reared from the M1 stage to the PZ1 stage at the lowest (25 ppt), and highest (45 ppt) salinity levels were 9 and 6\% (Figure 2).

Table 1. Survival percentages (mean \pm SD) of brown shrimp larvae (from N5 to PL stage) reared at different salinity levels at $27.6 \pm 0.4^{\circ} \mathrm{C}$ water temperature. N5/L-1: Total number of nauplii per litre, SR: survival rate (\%). *Different letters in the row indicate that the difference is statistically essential $(\mathrm{P}<0.05)$

\begin{tabular}{|c|c|c|c|}
\hline \multirow{2}{*}{$\begin{array}{c}\text { Salinity } \\
\text { (ppt) }\end{array}$} & \multirow[t]{2}{*}{ N5/L-1 } & \multicolumn{2}{|c|}{ SR (\%) } \\
\hline & & $\begin{array}{l}\text { Protozoea } \\
\text { (PZ1- M1) }\end{array}$ & Mysis (M1-PL1) \\
\hline 25 & 50 & $\begin{array}{l}14.00 \pm \\
4.89 \mathrm{bc}\end{array}$ & $9.20 \pm 4.60 a b^{*}$ \\
\hline 30 & 50 & $\begin{array}{c}41.20 \pm \\
17.35 \mathrm{a}\end{array}$ & $23.20 \pm 18.14 a$ \\
\hline 35 & 50 & $\begin{array}{l}44.00 \pm \\
23.15 a\end{array}$ & $24.40 \pm 19.51 a$ \\
\hline 40 & 50 & $\begin{array}{c}44.00 \pm \\
12.08 a\end{array}$ & $16.80 \pm 6.72 a$ \\
\hline 45 & 50 & $\begin{array}{l}31.20 \pm \\
16.16 \mathrm{ba}\end{array}$ & $6.00 \pm 1.41 b$ \\
\hline
\end{tabular}

The best survival rate between protozoea and mysis periods was found at 35, 40 and $30 \mathrm{ppt}$ salinity levels, respectively. The larvae reared at 25 and 45 ppt salinity levels had the lowest larval survivals from PZ1 to M1 (Figure1).

Considering the survival rates from the M1 stage to the PL1 period, the best survival rate was found at 35 ppt (24.40\%), 30 ppt (23.20\%), and 40 ppt
$(16.80 \%)$ salinity levels. The survival rate of the larvae reared from the M1 stage to the PZ1 stage at the lowest (25 ppt) and highest (45 ppt) salinity levels was $9 \%$ and $6 \%$ (Figure2).

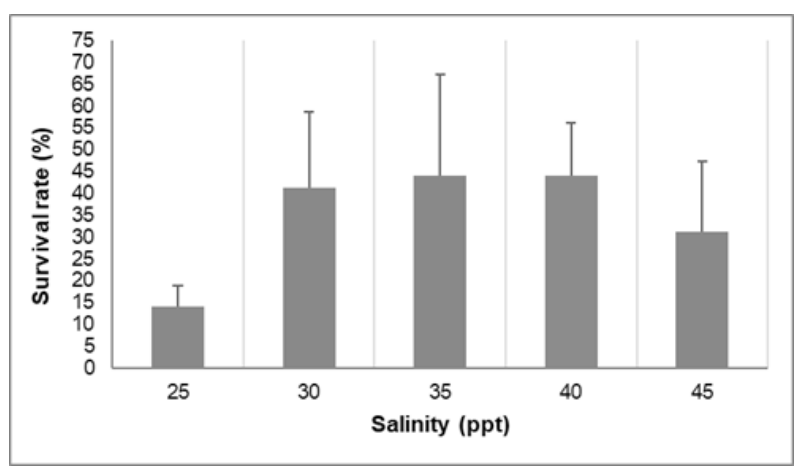

Figure 1. Survival rates of $F$. aztecus larvae from N5 to M1 stage (Protozoea stage) in different salinity levels

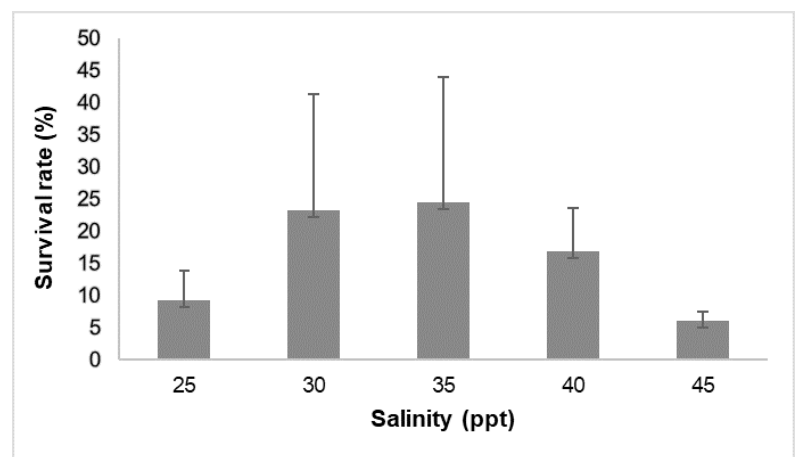

Figure 2. Survival rates of $F$ aztecus larvae from M1to PL1stage in different salinity levels

\section{Discussion}

It is known that shrimps belonging to the Penaeidae family prefers different salinity levels in different periods of their lives. For example, previous studies have reported that optimum salinity levels is 20-35 ppt for hatching brown shrimp eggs, 24.1-36 ppt for larval-postlarva production and development, 10-20 ppt for juveniles, and 24-26 ppt for spawners. (Zein-Eldin and Renaud, 1986; Pattillo et al., 1995; Pattillo et al., 1997; O'Connell et al., 2016).

In our current study, 30, 35, and 40 ppt salinity levels were the best survival rate for protozoeal and mysis stages. The survival rate at these levels did not differ between the groups. These salinity values are slightly higher than those reported in the literature for $F$. aztecus. This situation might be explained by adapting the broodstock shrimp stocks in the North-eastern Mediterranean salinity (38-39 ppt). Similarly, Kumlu (1998) reported a difference in larval salinity tolerance between 
Indian and the Red Sea strains of Penaeus indicus. In addition, it is stated in the literature that the salinity tolerance and survival rates of penaeid shrimps in the larval and post-larval periods are closely related to the environmental parameter such as salinity and temperature of the water in the spawning area of the broodstock (Preston, 1985; Lester and Pante, 1992).

The low survival rate in larval stages and the number of post-larvae obtained in our current study can be attributed to the quality of eggs obtained from a single spawning. Racotta et al. (2003) reported that naupliar quality depends principally on the physiological condition of broodstock but also on environmental conditions prevailing in spawning incubation tanks. Broodstock condition or maternal effects can also affect larval quality. The biochemical composition of the egg and nauplii also impacts the survival rate in reaching the postlarval stage (Hernandez-Herrare et al., 2001).

\section{Conclusion}

The present study was carried out to develop the larval culture protocol in salinity respect for the brown shrimp (Atlantic originate) in controlled conditions. The research results show that the optimum salinity levels at which the highest survival rate obtained from 30 to $40 \mathrm{ppt}$ for the for the North-eastern Mediterranean population of brown shrimp for the first time. It is thought that presenting this information for the benefit of stakeholders will contribute to both scientific studies and the practice of breeders.

\section{Acknowledgements}

We thank Dr. Selin Sayın (Iskenderun Technical University, TURKEY) for phytoplankton production and supply. This study (MSc thesis) was carried out under the supervision of Dr. Mevlüt Aktaș, who is a team member of the TÜBITAK 1001 project (1210713), within the scope of the preliminary studies realised to carry out biofloc applications for Farfantepenaeus aztecus culture.

\section{COMPLIANCE WITH ETHICAL STANDARDS}

Authors' Contributions

Authors contributed equally to this paper.

\section{Conflict of Interest}

The authors declare that there is no conflict of interest.

Ethical Approval

For this type of study, formal consent is not required.

\section{References}

Castaneda, R. P., Sanchez-Martinez, J. G. \& Guzman, G. A. (2012). Growth and survival of Brown shrimp (Farfantepenaeus aztecus) in a closed recirculation seawater system at different salinities. The Thai Journal of Veterinary Medicine, 42(1): 95-99.

Charmantier, G., Charmantier-Daures, M., Bouaricha, N., Thuet, P., Aiken, D. E. \& Trilles, J. P. (1988). Ontogeny of osmoregulation and salinity tolerence in two decapod crustaceans: Homarus americanus and Peneaus japonicus. The Biological Bulletin, 175(1): 102-110.

Chu, K. H. \& So, B. S. H. (1987). Changes in salinity tolerance during larval development of the shrimp Metapenaeus ensis (DE HAAN). Asian Marine Biology, 4: 41-48.

Deval, M. C., Kaya, Y. Güven, O., Gökoğlu, M. \& Froglia, C. (2010). An unexpected find of the western Atlantic shrimp, Farfantepenaeus aztecus (Ives, 1891) (Decapoda, Penaeidae) in Antalya Bay, eastern Mediterranean Sea. Crustaceana, 83: 1531-1537.

Gopalakrishnan, K. 1976. Larval rearing of red shrimp Penaeus marginatus (crustacea). Aquaculture, 9: 145-154.

Gökoğlu, M. \& Özvarol, Y. (2013). New Mediterranean marine biodiversity records: Biogeographic expansion of Farfantepenaeus aztecus (Ives, 1891) (Decapoda: Penaeidae) in the Eastern Mediterranean Sea. Mediterranean Marine Science, 14: 475-476.

Herna'ndez-Herrera, R., Perez-Rostro, C. I., Arcos, F., Ramírez, J. L., Ibarra, A. M., Palacios, E. \& Racotta, I. S. (2001). Predictive criteria of shrimp larval quality: an experimental approach. In: Hendry, C.I., Van Stappen, G., Wille, M., Sorgeloos, P. (Eds.), Larvi 2001 Fish and Crustacean Larviculture Symposium, Ghent, Belgium, pp. $242-245$.

Kapiris, K., Apostolidis, C., Baldacconi, R., Bașusta, N., Bilecenoğlu, M., Bitar, G., Bobori, D.C., Boyaci. Y.Ö., Dimitriadis, C., Djurović, M., Dulcic, J., Durucan, F., Gerovasileiou, V., Gökoğlu, M., Koutsoubas, D., Lefkaditou, E., Lipej, L., Marković, O., Mavrič, B., Özvarol, Y., Pesic, V., Petriki, O., Siapatis, A., Sini, M., Tibullo, D. \& Tiralongo, F. (2014). New Mediterranean marine biodiversity records. Mediterranean Marine Science, 15: 198-212.

Kumlu, M. \& Jones, D.A. (1995). Salinity tolerance of hatchery-reared postlarvae of Penaeus indicus H. Milne Edjwards originating from India. Aquaculture, 130: $287-296$

Kumlu, M. (1998). The effect of salinity on larval growth and survival of Penaeus indicus (Decapoda: Penaeidae). Turkish Journal of Zoology, 22: $163-167$.

Kumlu, M., Eroldogan, 0. T. \& Aktas, M. (1999). The effect of salinity on larval growth, survival and development of Penaeus semisulcatus (Decapoda: Penaeidae). Israeli Journal of Aquaculture-Bamidgeh, 51(3): 114-121.

Kumlu, M., Eroldogan, 0. T. \& Aktas, M. (2000). Effects of temperature and salinity on larval growth, survival and development of Penaeus semisulcatus, Aquaculture,188: 167-173. 
Lester L. J. \& Pante M. J. R. (1992). Penaeid temperature and salinity responses. In: Marine Shrimp Culture: Principles and Practices (Ed. by A.W. Fast \& L.J. Lester), pp. 515- 533. Elsevier Science Publishers, Amsterdam.

Minos, G., Kokokiris, L., Imsiridou, A., Karachle, P. \& Kapiris, K. (2015). Notes on the distribution and biology of northern brown shrimp Farfantepenaeus aztecus (Ives, 1891) in the Eastern Mediterranean. Turkish Journal of Zoology, 39: 1-7.

O'Brien, C. J. (1994). The effects of temperature and salinity on growth and survival of juvenile tiger prawn Penaeus esculentus. Journal of Experimental Marine Biology and Ecology, 183(1): 133-145.

Parado-Estepa, F. D. (1998). Survival of Penaeus monodon postlarvae and juveniles at different salinity and temperature levels. The Israeli Journal of Aquaculture-Bamidgeh, 50(4): 174-183.

Staples, D. J. \& Heales, D. S. (1991). Temperature and salinity optima for growth and survival of juvenile banana prawn Penaeus merguiensis. Journal of Experimental Marine Biology and Ecology, 154: 251-274.

Pérez Farfante, I. (1969). Western Atlantic shrimps of the genus Penaeus. Fishery Bulletin, 67: 461-591.

Venkataramaiah, A., Lakshmi, G. J. \& Gunter, G. (1972). The effects of salinity, temperature and feeding levels on the food conversion, growth and survival rates of the shrimp Penaeus aztecus. Marine Technology Society Food-Drugs from the Sea Proceedings, 29-42.

Preston, N. (1985). The effects of temperature and salinity on survival and growth of larval Penaeus plebejus, Metapenaeus macleayi and M. bennettae. $2^{\text {nd }}$ Australian Natt. Prawn Seminar, 31-40.

Racotta, I. S., Palacios, E. \& Ibarra. A. M. (2003). Shrimp larval quality in relation to broodstock condition. Aquaculture, 227(1-4): 107-130.

Soud, P. \& Davis, D. A. (2003). Salinity tolerance of Brown shrimp Farfantepenaeus aztecus as it relates to post larval growth and juvenile survival, distribution and growth in estuaries. Estuaries, 26(4): 970-974.

Xinhong, S., Changchun, S., Zhangwu, Y. \& Yayou, Z. (2005). Effect of low salinity on the survival of postlarvae of the blue shrimp, at different stages. The Israeli Journal of Aquaculture-Bamidgeh, 57(4): 271-277.

Zein- Eldin, Z. P. \& Griffith, G. V. (1965). The effect of temperature upon the growth of laboratory-held postlarval Penaeus aztecus. Biological Bulletin, 131(1): 186-196. 